\title{
Development of Brown Patch and Pythium Blight in Tall Fescue as Affected by Irrigation Frequency, Clipping Removal, and Fungicide Application
}

\author{
D. M. Settle and J. D. Fry, Department of Horticulture, Forestry and Recreation Resources, Kansas State Univer- \\ sity, Throckmorton Plant Sciences Center, Manhattan 66506; and N. A. Tisserat, Department of Plant Pathology, \\ Kansas State University
}

\begin{abstract}
Settle, D. M., Fry, J. D., and Tisserat, N. A. 2001. Development of brown patch and Pythium blight in tall fescue as affected by irrigation frequency, clipping removal, and fungicide application. Plant Dis. 85:543-546.

We studied the effects of irrigation frequency, clipping removal, and fungicide application on the development of Rhizoctonia brown patch (Rhizoctonia solani) and Pythium blight (Pythium aphanidermatum) in tall fescue. Brown patch severity was not significantly different between plots irrigated daily and those irrigated on alternate days. Similarly, no differences in brown patch were observed in plots where grass clippings were returned to the sward with a mulching mower compared with plots where clippings were removed. Preventive applications of azoxystrobin at 35-day intervals or postinfection applications of chlorothalonil reduced brown patch severity, but only the azoxystrobin treatment provided aesthetically acceptable $(<10 \%)$ levels of brown patch control. However, azoxystrobin applications also increased Pythium blight compared with untreated or chlorothalonil-treated tall fescue, especially in plots that received daily irrigation.
\end{abstract}

Tall fescue (Festuca arundinacea Schreb.) is an important cool-season turfgrass in the North American transition zone. It is widely used because it is adapted to a broad range of soil conditions, is tolerant to drought and heat, and is easy to establish from seed. Several fungal pathogens can detrimentally affect the quality of tall fescue swards. Rhizoctonia brown patch, caused by Rhizoctonia solani Kühn, is the most common disease in the Great Plains region from late May through early September. Pythium blight, caused by Pythium aphanidermatum (Edson) Fitzp., also damages tall fescue during hot, wet summer weather (16), but it is observed infrequently in Kansas.

Environmental awareness, limited landfill space, and the growing cost of waste disposal has increased the practice of returning grass clippings to the sward. The influence of returning clippings on the development of brown patch and Pythium blight on tall fescue is undetermined. $R$. solani can survive up to 4 months on perennial ryegrass clippings (15), and returning clippings can increase brown patch in this species (7). Returning clippings apparently also increases severity of Pythium blight in creeping bentgrass and perennial

Corresponding author: N. A. Tisserat

E-mail: tissne@plantpath.ksu.edu

Accepted for publication 2 February 2001.

Publication no. D-2001-0319-01R

(C) 2001 The American Phytopathological Society ryegrass (16). Therefore, recycled grass clippings may provide a source of inoculum for brown patch and Pythium blight development in tall fescue.

Irrigation timing and frequency also may affect brown patch development. Perennial ryegrass receiving evening irrigation in Maryland consistently exhibited greater brown patch severity than turf irrigated in early morning (9). Daily, early-morning irrigation in Kansas suppressed brown patch in perennial ryegrass compared with irrigation 3 days weekly (11).

Several fungicides have been shown to provide control of brown patch on tall fescue and may be suitable for use in preventive or postinfection programs by lawn care operators (17). However, their use has been limited because of cost, number of applications required, and difficulty in timing treatments.

The objectives of our research in tall fescue were to evaluate the effect of irrigation frequency, clipping removal, and fungicide application strategies on brown patch and Pythium blight development.

\section{MATERIALS AND METHODS}

The study was conducted at the Rocky Ford Research Center in Manhattan, KS, during the summers of 1998 and 1999. Soil was a Chase silt loam (fine, montmorillonitic, mesic, Aquic Arquidolls). A blend consisting of 20\% Tomahawk, 20\% Apache II, $20 \%$ Coronado, 20\% Safari, 15\% Barlexas, and 5\% Tar Heel was seeded on 18 September 1997 at $342 \mathrm{~kg} \mathrm{ha}^{-1}$. Turf received $49 \mathrm{~kg}$ $\mathrm{N} \mathrm{ha}^{-1}$ from urea in September, October, April, May, and June 1998 and 1999.
The effects of irrigation frequency, clipping management, and fungicide application strategies were studied in a split-split plot design with three replications. Whole plots measured $8.5 \times 15.2 \mathrm{~m}$ and consisted of daily versus 3 to 4 days weekly irrigation schedules (hereafter referred to as "alternate") that began in May and ended in October of each year. Pop-up, gear driven Nelson 6000 irrigation heads (L. R. Nelson, Peoria, IL) were used to deliver water to plots. In 1998, plots were irrigated daily at $0430 \mathrm{~h}$ or on Monday, Wednesday, and Friday at $0500 \mathrm{~h}$. For both treatments, the amount of water applied at each irrigation was equal to $100 \%$ of the estimated evapotranspiration (ET) that occurred since the previous irrigation. Evapotranspiration was estimated using Bellani plate atmometers as described by Qian et al. (13). Actual amounts of water applied during the summer ranged from 1 to $13 \mathrm{~mm}$ per day. In 1999, daily irrigated plots received 5 $\mathrm{mm}$ of water per day regardless of ET. In June and July, daily irrigation was split into three 6-min intervals applied at 0100 , 0300 , and $0500 \mathrm{~h}$. The irrigation schedule was returned to a single 18-min application at $0400 \mathrm{~h}$ on 3 August. Turf irrigated on the alternate day schedule received $10 \mathrm{~mm}$ of water every other day at $1000 \mathrm{~h}$.

Two grass clipping management subplots, measuring $4.3 \times 15.2 \mathrm{~m}$ and randomly arranged within each irrigation whole plot, consisted of collection and removal of clippings or returning clippings to the sward. Both subplots were mowed with a rotary mower every 3 to 4 days at a height of $9.0 \mathrm{~cm}$.

Three fungicide treatment sub-subplots measuring $3.0 \times 3.0 \mathrm{~m}$ were randomly arranged within each mowing subplot and consisted of: (i) untreated turfgrass; (ii) a preventive application of azoxystrobin (methyl (E)-2-\{2-[6-(2-cyanophenoxy) pyrimidin-4-yloxy]phenyl\}-3-methoxyacrylate) at 35-day intervals; and (iii) a postinfection application of chlorothalonil (tetrachloroisophthalonitrile) within $12 \mathrm{~h}$ of the visible appearance of brown patch. Postinfection applications continued at 2-week intervals during brown patch activity (i.e., when an increase in blighting had occurred since the last rating). Azoxystrobin (Heritage 50 WG) was applied preventively at $0.3 \mathrm{~kg}$ a.i. $\mathrm{ha}^{-1}$ on 29 May, 3 July, and 7 August 1998 and 4 June, 9 July, and 13 August 1999. Postinfection treatments of chlor- 
othalonil (Daconil Ultrex 82.5 WDG) at $9.6 \mathrm{~kg}$ a.i. $\mathrm{ha}^{-1}$ were applied on 3 and 28 July 1998 and 24 June, 26 July, and 30 August 1999. Fungicides were applied with a $\mathrm{CO}_{2}$-pressurized backpack sprayer calibrated to deliver 260 liters ha $^{-1}$ through 8003 flat-fan nozzles.

Plots were rated weekly by visually determining the percent plot area blighted (foliar necrosis) by brown patch and Pythium blight. Disease development was a result of natural infection. $R$. solani AG1$1 \mathrm{~A}$ and $P$. aphanidermatum were consistently isolated from blighted leaves of plants exhibiting brown patch and Pythium blight symptoms, respectively, at the beginning of each epidemic in each year. The presence of $R$. solani hyphae and $P$. aphanidermatum hyphae and oospores in blighted leaves was periodically confirmed during epidemics by microscopic examination. Blight percentages were used to calculate the area under the disease progress curve (AUDPC) in each year (4). To assess residual turfgrass injury, four 10.1$\mathrm{cm}$-diameter turf cores were randomly removed 17 August 1998 and 14 May 1999 from untreated and the azoxystrobintreated sub-subplots and from all subsubplots 1 October 1999. Numbers of grass tillers were counted in each of the four cores and averaged for each sub-subplot. Analysis of variance on all ratings was performed with the PROC MIXED proce-
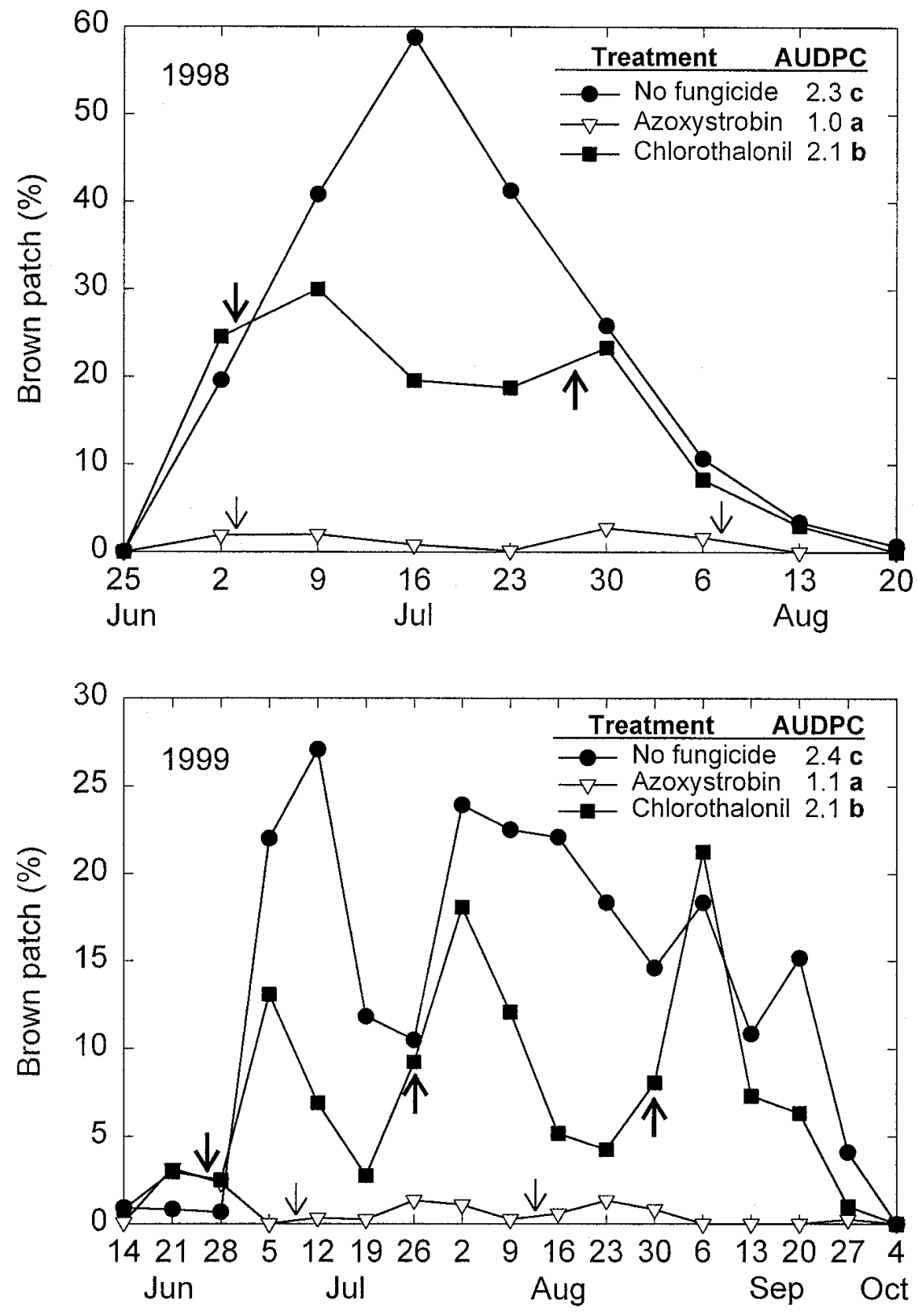

Fig. 1. Effect of fungicide applications on brown patch development in tall fescue. Symbols beneath the date represent days on which $(\uparrow)$ preventive (azoxystrobin) or $(\uparrow)$ postinfection (chlorothalonil) treatments were applied. Area under the disease progress curve (AUDPC) treatment means $\log _{10}(X+$ 1) transformed prior to analysis. Means followed by the same letter are not significantly different $(P$ $\leq 0.05)$.

dure (SAS Institute, Cary, NC) and used a Saterthwaite adjustment for split-split plot analysis of variance (12).

\section{RESULTS}

In 1998, a single, severe brown patch epidemic occurred beginning 3 July (Fig. 1). Initial blighting developed in distinct, irregularly shaped patches, but as the epidemic progressed, a more diffuse blighting was observed. Individual grass blades exhibited straw-colored lesions with dark red margins, and on mornings of disease activity, weblike fungal mycelium was visible on leaf blades. By 13 July, $58 \%$ of the area in nontreated plots was blighted. The brown patch epidemic was followed by two minor Pythium blight outbreaks on 7 August and 9 September (Fig. 2). Pythium blight appeared as sunken, blighted areas $10 \mathrm{~cm}$ or less in diameter. Infected leaf blades initially developed water-soaked lesions near the crown that lacked distinct margins. Blighted leaves quickly collapsed and rotted, resulting in a matted appearance to the patch. In 1999, three moderate brown patch outbreaks (21 June, 23 July, and 27 August) resulted in blighted turf from mid-June through mid-September (Fig. 1). A concomitant epidemic of Pythium blight occurred from late July through early September.

No interactions $(P>0.05)$ were observed among irrigation frequency, clipping removal, and fungicide treatments on brown patch development in 1998 or 1999. There also were no differences $(P>0.05)$ in AUDPC between daily and alternate day irrigation schedules or clipping removal and clipping recycling treatments in either year, and these data were combined for analysis. Irrigation and mowing treatments did not affect shoot density except in August 1998, when a combination of daily irrigation and returning grass clippings reduced shoot density (Table 1).

Preventive and postinfection fungicide treatments suppressed brown patch in both years (Fig. 1). Preventive applications of azoxystrobin at 35-day intervals resulted in $>95 \%$ brown patch control. Postinfection applications of chlorothalonil were less effective. Because of rapid blighting during early stages of the epidemic, plots sustained 5 to $25 \%$ visual damage before chlorothalonil was applied. Furthermore, blight increased slightly for approximately 4 days after treatment as leaves with incipient infections at the time of fungicide application wilted and died. Nevertheless, chlorothalonil suppressed blighting by 25 to $50 \%$ during individual brown patch outbreaks and reduced the AUDPC compared with nontreated plots in both years. The total number of applications required for the postinfection spray program was two in 1998 (3 July and 28 July) and three in 1999 (24 June, 26 July, and 30 August).

Pythium blight was not influenced by differences in irrigation frequency in 1998 
or clipping management in either year $(P>$ $0.05)$. Blighting was enhanced in plots treated with azoxystrobin in 1998 (Fig. 2). In 1999, a significant irrigation frequency by fungicide treatment interaction was observed. Pythium blight predominantly occurred in azoxystrobin-treated plots receiving daily irrigation (Fig. 2). No other treatment combination exacerbated Pythium blight.

Tall fescue shoot density in the azoxystrobin-treated plots was higher than in untreated plots in August 1998 and in untreated or chlorothalonil-treated plots in October 1999 (Table 1). In contrast, shoot densities between azoxystrobin-treated and untreated plots were not significantly different in May 1999.

\section{DISCUSSION}

We hypothesized that daily, earlymorning applications of water would remove dew and guttation droplets from tall fescue leaves, hasten early-morning leaf drying, and reduce brown patch severity. Rowell (14) observed that brown patch failed to develop on $R$. solani-inoculated creeping bentgrass plots given overhead irrigation. He speculated that irrigation suppressed brown patch by preventing guttation drops from forming on leaves and inhibiting colonization by $R$. solani. Jiang et al. (11) found that brown patch on perennial ryegrass was decreased by daily irrigation compared with irrigation three times weekly. We did not detect differences in brown patch severity between daily and alternate day irrigation regimes. The higher mowing heights and dense canopy structure of tall fescue may have prevented efficient dew removal and rapid drying of leaves following early-morning irrigation. Alternatively, rapid dew accumulation following moisture displacement, as described by Williams et al. (21), may have prevented a disruption in leaf wetness duration.

The use of mulching mowers that return clippings to the sward is recommended, especially in higher mowed turfgrasses in residential landscapes, because it recycles nutrients contained in leaf blades and reduces the disposal of clippings in landfills $(2,8,19,20)$. However, there is concern that returning diseased clippings may increase the severity of certain fungal diseases $(5,7,10,16)$. We did not detect increases in brown patch or Pythium blight in tall fescue associated with recycling grass clippings. Recycling clippings in daily irrigated plots did result in a slight reduction of shoot density in August 1998, but this trend was not observed in 1999.

Brown patch resulted in $>10 \%$ turf blighting in untreated plots for three or more weeks during a 4-month period in each year of the study. This level and duration of blighting may be unacceptable in high-maintenance lawns. The fungicide azoxystrobin has previously been shown to provide long-lasting protection against brown patch in other turfgrasses $(6,18)$ and has been detected in tall fescue and creeping bentgrass leaves 46 days after application (1). We found that three azoxystrobin applications at 35-day intervals beginning in early June provided almost complete control of brown patch. This was true even though the rates we used $\left(0.3 \mathrm{~kg}\right.$ a.i. ha $\left.{ }^{-1}\right)$ were half the monthly application rates currently labeled for brown patch suppression on cool-season turfgrasses. Periodic preventive applications of azoxystrobin could be integrated into existing landscape maintenance programs relatively easily since turfgrass managers in Kansas often return to residential lawns at 4- to 5-week intervals for fertilizer, herbicide, or insecticide applications.
Azoxystrobin currently is labeled for control of Pythium blight on several turfgrass species. We found that Pythium blight on tall fescue was higher in azoxystrobin-treated plots in both years, especially in daily irrigated plots. Poor control of Pythium blight caused by $P$. aphanidermatum on tall fescue also has been reported in Georgia (3). It is possible that the low rates and extended application intervals of azoxystrobin we used were not sufficient to suppress Pythium blight. Additionally, turf treated with azoxystrobin was more dense in mid- to late summer than either the chlorothalonil-treated or untreated plots as a result of superior brown patch control. Lush, dense turf favors Pythium blight development (16). We found that reducing irrigation frequency
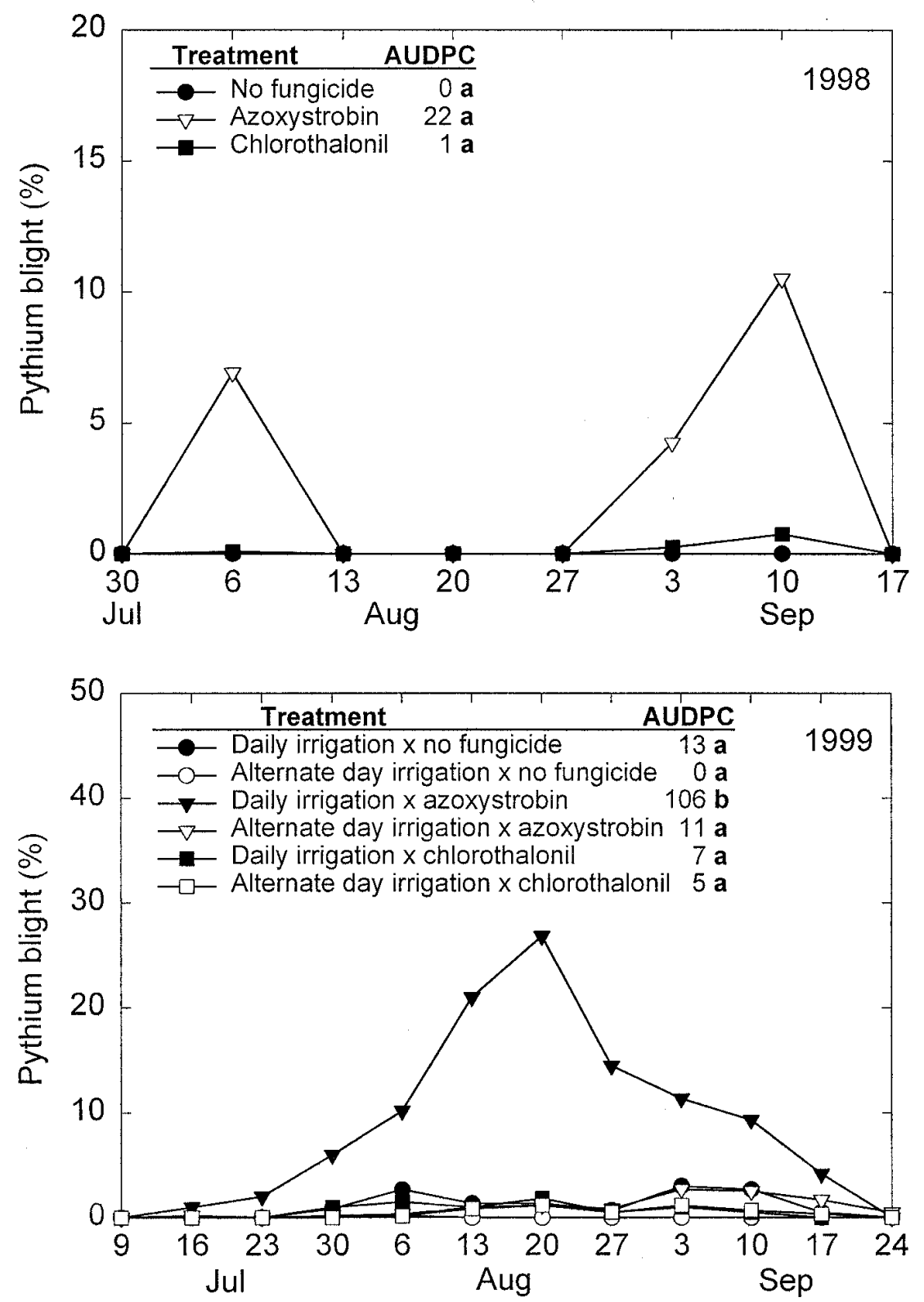

Fig. 2. Effect of fungicide applications (1998) and fungicide applications and irrigation frequency (1999) on Pythium blight development in tall fescue. Areas under the disease progress curve (AUDPC) means followed by the same letter are not significantly different $(P \leq 0.05)$. 
Table 1. Irrigation frequency, clipping removal and fungicide application treatment effects on shoot density of tall fescue following epidemics of brown patch and Pythium blight

\begin{tabular}{|c|c|c|c|}
\hline \multirow[b]{2}{*}{ Treatment } & \multicolumn{3}{|c|}{ Shoot density (tillers $\mathrm{cm}^{-2}$ ) } \\
\hline & 17 Aug 1998 & 14 May 1999 & 1 Oct 1999 \\
\hline \multicolumn{4}{|l|}{ Irrigation } \\
\hline Daily & $1.5 \mathrm{a}^{\mathrm{x}}$ & $1.8 \mathrm{a}$ & $1.5 \mathrm{a}$ \\
\hline Alternate day & $1.6 \mathrm{a}$ & $2.0 \mathrm{a}$ & $1.5 \mathrm{a}$ \\
\hline \multicolumn{4}{|l|}{ Mowing } \\
\hline Return clippings & $1.5 \mathrm{a}$ & $1.9 \mathrm{a}$ & $1.4 \mathrm{a}$ \\
\hline Remove clippings & $1.6 \mathrm{a}$ & $1.8 \mathrm{a}$ & $1.5 \mathrm{a}$ \\
\hline \multicolumn{4}{|l|}{ Irrigation $\times$ mowing } \\
\hline Daily + return clippings & $1.4 \mathrm{a}$ & $1.9 \mathrm{a}$ & $1.4 \mathrm{a}$ \\
\hline Daily + remove clippings & $1.6 \mathrm{~b}$ & $1.7 \mathrm{a}$ & $1.4 \mathrm{a}$ \\
\hline Alternate day + return clippings & $1.7 \mathrm{~b}$ & $2.0 \mathrm{a}$ & $1.5 \mathrm{a}$ \\
\hline Alternate day + remove clippings & $1.5 \mathrm{ab}$ & $2.0 \mathrm{a}$ & $1.5 \mathrm{a}$ \\
\hline \multicolumn{4}{|l|}{ Fungicide } \\
\hline Untreated & $1.2 \mathrm{~b}$ & $1.9 \mathrm{a}$ & $1.1 \mathrm{c}$ \\
\hline Azoxystrobin & $1.9 \mathrm{a}$ & $1.9 \mathrm{a}$ & $1.9 \mathrm{a}$ \\
\hline Chlorothalonil & $\ldots{ }^{y}$ & $\ldots$ & $1.4 \mathrm{~b}$ \\
\hline
\end{tabular}

${ }^{x}$ Values within a column by treatment or by irrigation $\times$ mowing interaction followed by the same letter are not significantly different according to a least significant difference test $(P \leq 0.05)$. There were no irrigation $\times$ fungicide or mowing $\times$ fungicide interactions $(P>0.05)$.

${ }^{y}$ Data not recorded.

moderated Pythium blight development in azoxystrobin-treated tall fescue.

Postinfection fungicide applications are commonly used by turf managers to control brown patch on tall fescue in residential landscapes. In our study, tall fescue often exhibited $>10 \%$ blighting before a postinfection application of chlorothalonil could be made. While postinfection applications suppressed further brown patch development, the overall damage to the plots was still unacceptable. This lack of control would likely be true for any fungicide used in a postinfection schedule because of the latent period between infection and initial symptom development.

The use of fungicides to suppress brown patch and maintain stand density may not be warranted on lower maintenance lawns provided that some transient decrease in turfgrass quality during the summer can be tolerated. We observed that tall fescue shoot density was reduced in untreated versus azoxystrobin-treated plots immediately following brown patch epidemics in late summer, but these differences were not apparent by the following spring. This suggests that $R$. solani was primarily damaging leaves and tillers and not killing crowns of individual plants. It also indicates that tall fescue swards can recover from brown patch injury during periods unfavorable for brown patch development.

\section{ACKNOWLEDGMENTS}

This research was sponsored in part by the Kansas Turfgrass Foundation, the Kansas Golf Course Superintendents Association, and the Heart of America Golf Course Superintendents Association. We thank G. Milliken and T. Todd for statistical advice.

\section{LITERATURE CITED}

1. Bartlett, D. W., Kingston, G. A., and Ross, D. C. 1998. Azoxystrobin: Uptake and redistribution in turfgrass. Phytopathology 88:S6.

2. Beard, J. B. 1973. Turfgrass: Science and Culture. Prentice-Hall, Englewood Cliffs, NJ.

3. Burpee, L. L., Green, D. E., and Stephens, S. L. 1995. Turfgrass Pathology Annual Research Report, University of Georgia, Athens.

4. Campbell, C. L., and Madden, L. V. 1991. Introduction to Plant Disease Epidemiology. John Wiley \& Sons, New York.

5. Couch, H. B. 1995. Diseases of Turfgrasses. 3rd ed. Krieger Publ., Malabar, FL.

6. Dernoeden, P. H., and Krouse, J. M. 1998. Brown patch and red leaf spot control with DMI fungicides; 1997. Fungic. Nematicide Tests 53:431

7. Dunn, J. H., Minner, D. D., Fresenburg, B. F., and Bughrara, S. S. 1996. Clippings disposal and fertilization influence disease in perennial ryegrass turf. HortScience 31:1180-1181.

8. Emmons, R. D. 1995. Turfgrass Science and Management. 2nd ed. Delmar Publishers, Albany, NY.

9. Fidanza, M. A., and Dernoeden, P. H. 1996. Brown patch severity in perennial ryegrass as influenced by irrigation, fungicide, and fertilizers. Crop Sci. 36:1631-1638.

10. Hagan, A. K., and Larsen, P. O. 1985 Source and dispersal of conidia of Dre chslera poae in Kentucky bluegrass turf. Plant Dis. 69:21-24.

11. Jiang, H., Fry, J. D., and Tisserat, N. A. 1998. Assessing irrigation management for its effects on disease and weed levels in perennial ryegrass. Crop Sci. 38:440-445

12. Milliken, G. A., and Johnson, D. E. 1984 Analysis of Messy Data. Vol. I: Designed Experiments. Lifetime Learning Pub., Belmont, CA.

13. Qian, Y. L., Fry, J. D., Wiest, S. C., and Upham, W. S. 1996. Estimating turfgrass evapotranspiration using atmometers and the Penman-Monteith model. Crop Sci. 36:699704.

14. Rowell, J. B. 1951. Observations on the pathogenicity of Rhizoctonia solani on bentgrasses. Plant Dis. Rep. 35:240-242.

15. Shurtleff, M. C. 1953. Factors that influence Rhizoctonia solani to incite turf brown patch (Abstr.) Phytopathology 43:484.

16. Smiley, R. W., Dernoeden, P. H., and Clarke, B. B., eds. 1992. Compendium of Turfgras Diseases. 2nd ed. American Phytopathological Society, St. Paul, MN.

17. Tisserat, N. A., and Pair, J. C. 1997. Preventive fungicide applications for control of Rhizoctonia brown patch of tall fescue, 1996 Fungic. Nematicide Tests 52:391.

18. Tredway, L. P., and Clarke, B. B. 1998. Control of brown patch with chemical and biological fungicides, 1997. Fungic. Nematicide Tests 53:435

19. Turgeon, A. J. 1991. Turfgrass Management. 3rd ed. Prentice-Hall, Englewood Cliffs, NJ

20. Vargas, J. M. 1994. Management of Turfgrass Diseases. Lewis Publishers, Boca Raton, FL.

21. Williams, D. W., Powell, A. J., Dougherty, C. T., and Vincelli, P. 1998. Separation and quantitation of the sources of dew on creeping bentgrass. Crop Sci. 38:1613-1617. 